\title{
Black American Literature and the Problem of Racism, Slavery and Oppression in the Post Slavery Era: A Reappraisal of Dunbar's The Sport of the Gods.
}

\author{
Mbanefo S. Ogene \\ DOI: http://dx.doi.org/10.4314/ujah.v14i1.4
}

\section{Abstract}

The problem created by racism could be traced to be the major factor behind most Black literature through the ages. In America, this gave rise to a new form of literary expression known as the Black American Literature or African American Literature. The main concern of this sub-genre of literature is to redeem the face of the black man and his culture from the negative to a more positive direction. This study reappraises the development of Black American Literature from the $18^{\text {th }}$ century writers, like Phyllis Wheatley and Olaudah Equiano, to Post slavery era writers, especially of an author like Paul Lawrence Dunbar. Focusing on Dunbar's The Sport of the Gods, the paper exposes a sad situation where the blacks were made the spectacle (sport) of the whites (gods). Berry Hamilton (a Black American) is used in this novel to share the life story and experiences of other blacks with the readers especially about their encounters with their Slave Masters.

\section{Introduction and Historical Perspectives to the Black American Literature}

Black American Literature or African American Literature is a term that refers to a totality of published literature in the United States by writers of African descent. This genre of literature is traceable to the works of such late $18^{\text {th }}$ century writers like Phillis Wheatley and Olaudah Equiano. It got to its highest point with slave narratives and the Harlem Renaissance, and continues today with the works of authors 
like Toni Morrison, Maya Angelou and Walter Moseley who are recognized as the top writers in the United States. According to Encyclopaedia Britannica "Harlem Renaissance also called New Negro Movement is a period of outstanding literary vigour and creativity that took place in the 1920s, changing the character of literature created by black Americans, from quaint dialect works and conventional imitations of white writers to sophisticated explorations of black life and culture that revealed and stimulated a new confidence and racial pride." (Ultimate Reference). The black ghetto of Harlem, in New York City was the centre of this movement that encouraged the black budding artists, including writers and musicians who usually gathered to share their experiences and also encourage one another. Among the themes and issues explored in African American literature are the role of African Americans within the larger American society, African - American culture, racism, slavery, and equality. Other issues included in this type of genre are the oral forms of literature like spirituals, sermons, gospel music, blues and rap.

The change of attitude to the African Americans over the past centuries has equally affected the foci of the Black American literature. The primary focus of this literature before the American Civil War was on slavery, as the slave narratives indicate. This was changed at the turn of the $20^{\text {th }}$ century by the books of authors like Richard Wright and Gwendolyn Brooks who emphasized on the issues of racial segregation and Black Nationalism. Wikipedia states that:

African American literature has become accepted as an integral part of American literature, with books such as Roots: the Saga of an American Family by Alex Haley, The Color Purple by Alice Walker, and Beloved by Toni Morrison achieving both best-selling and awardwinning status. (Internet) 
African American literature has generally focused on themes of particular interest to Black people in the United States, such as the role of African Americans within the larger American society and what it means to be an American. Other characteristics of American literature include the position of the black Americans on the matter of freedom, as propagated by the American nation, equality that the black people lacked in the United States, and also the themes of culture of black American religion, racism, slavery and nostalgia. The Black American literature forms a good arm of the literature being both influenced by the great African diasporic heritage and equally having an influence on African diasporic writings on many countries.

Lucy Terry who wrote "Bars Fight", published in 1746 is referred to as the author of the oldest piece of African American literature. Terry's poem was not published until 1885, when it was published in Josiah Holland's "History of Western Massachusetts". (Adams:1289) In 1761, Jupiter Hammon published his poem "An Evening Thought: Salvation by Christ with Penitential Cries" (African - American Literature, Wikipedia : Web) This was followed by the poet Phillis Wheatley's Poems on Various Subjects published in 1773, three years before American independence. Wheatley (1753 - 1784) was born in Senegal, Africa. She was captured and sold into slavery at the age of seven, and subsequently brought to America and purchased by a Boston merchant. Through her fast mastery of the English Language she wrote well acknowledged poetry that received the acclaim of the leading figures of the African Revolution, including George Washington, who was reported to have "personally thanked her for a poem she wrote in his honour." (Gates: 214)

William Wells Brown (1814 - 1884) and Victor Sejour (1817 - 1874) are said to have produced the earliest works of 
fiction by African American writers. Sejour was born free in New Orleans and moved to France at the age of nineteen. There he published his short story "Le Mulatre" ("The Mulatto") in 1837. The story is said to represent the first known fiction by an African American, but written in French and published in a French journal. Brown on the other hand was a prominent abolitionist, lecturer, novelist, playwright, and historian. Born into slavery in the Southern United states, Brown escaped to the North, where he worked for abolitionist causes and was as well a prolific writer. He wrote what is considered to be the first novel by an African American, entitled Clotel, or, The President's Daughter (1853). The novel is based on what was at that time considered to be a rumour about Thomas Jefferson fathering a daughter with his slave, Sally Hemmings. The book is however not considered the first African novel published in the United States because it was published in England. Harriet Wilson is however acclaimed because of the novel Our Nig (1859) which details the difficulties in the lives of Northern free Blacks. (African American Literature, Wikipedia: Web)

After the end of slavery and the American Civil War, a number of African American authors continued to write nonfiction works about the condition of African Americans in the country. Notable among them are W.E.B. DU Bois (1868 1963) who published The Souls of Black Folk. Another prominent author of this period, Booker T. Washington however differed with DU Bois. Washington (1856 - 1915) published Up from Slavery (1901), The Future of the American Negro (1899), Tuskegee and its People (1905), and My Larger Education (1911). (African - American Literature, Wikipedia : Web)

Paul Lawrence Dunbar (1872 - 1906). Dunbar is categorized under the Post slavery era writers of the Black American literature. He often wrote in the rural, "black dialect" of the 
day. Dunbar was the first African American poet to gain national prominence. His first book of poetry, Oak and Ivy was published in 1893. Much of Dunbar's work, such as When Malindy Sings (1906), which includes photographs taken by the Hampton Institute Camera Club, and Joggin, Erlong (1906) provides revealing glimpses into the lives of rural African Americans of the day. Though Dunbar died young, he was a prolific poet, essayist, novelist and short story writer (His works include The Uncalled, 1898 and The Fanatics, 1901). $\mathrm{He}$ is also noted to have written most of his poems in African American dialect. Some of his other works are: The Uncalled, 1898 and The Fanatics, 1901. For most of his career, Dunbar wrote for a white audience and he generally avoided racial issues as his subject. The Sport of the Gods is referred to as Dunbar's best known novel (Encarta). Published first in 1902 by Dodd, Mead \& Co., New York, the novel tells a story of a black family in a Northern city in the United States of America. This family apparently suffered from racism, slavery and oppression, although this looks very passive in the plot of the novel. Dunbar also wrote four collections of short stories. His Collected poems appeared in 1913

\section{Analysis of Dunbar's The Sport of the Gods}

With its eighteen chapters, The Sport of the Gods is a fiction that narrates the life story and experiences of a Black American family, Berry Hamiltons and their Slave Master, Maurice Oakley. The novel's simple and direct form of expression makes it possible for the reader to easily decode the message or theme; that is, that of a family suffering under the clutches of slavery. Essentially, oppression, racial segregation, brutality and other negative tendencies of man's inhumanity to man are the main issues that make up the novel. 
Chapter One of the novel which talks about "The Hamiltons" exposes the reader to the old days of plantations, the overseers and masters and slaves. The little cottage in which Berry Hamilton lived as housekeeper, with his wife Fanny, a son Joe, and daughter Kitty, is sharply contrasted with the mansion of his employer which sat back some hundred paces away from the building, erected in the manner of the old cabin in the quarters, creating an opportunity for familiarity between the master and servant. The development of the old cabin to the modern neatly furnished home of a typical good-living Negro is certainly a mark of improvement in the liberation struggles to free Southern American culture of slavery in the plantations. Berry Hamilton had served for twenty years as Butler to Maurice Oakley. The reader is informed that,

He was one of the many slaves who upon their accession to freedom had not left the South, but had wandered from place to place in their own beloved section, waiting, working and struggling to rise with its rehabilitated fortunes. (Dunbar, 2)

It was the patience and hard work of Berry Hamilton that enabled him to rise to some fortune with his master Oakley, from the point of the latter's bachelorhood to the stage of marriage. As Maurice Oakley married his wife, Berry equally married the housekeeper Fannie and they lived happily after. Their two children Joe and Kitty were born under this atmosphere of peace and comfort. In the usual slave order, Kitty started helping her mother, while Joe learnt the barbing skill.

As part of their sense of belonging, Kitty has a gift of singing and she sings for the A.M.E. Church or for the Tribe of Benjamin. Dunbar states that "the girl did have the prettiest clothes of any of her race in the town, and when she was to sing for the benefit of the A. M. E. Church or for the benefit of 
her father's society, the Tribe of Benjamin, there was nothing too good for her to wear." (5) Mrs. Oakley took a lively interest in the girl Kitty and encouraged her fine dressings. Their bourgeoisie 'spoiling of their children' much as the 'white fathers and mothers' did were not without the expected jealousies of other less fortunate Negroes of the community.

According to Dunbar:

Joe and Kit were respectively eighteen and sixteen at the time when the preparations for Maurice Oakley's farewell dinner to his brother Francis were agitating the whole Hamilton household. All of them had a hand in the work: Joe had shaved the two men; Kit had helped Mrs. Oakley's maid; the mother had fretted herself weak over the shortcomings of a cook that had been in the family nearly as long as herself, while Berry was stern and dignified in anticipation of the glorious figure he was to make in serving. (6)

Chapter Two of the novel entitled "A Farewell Dinner" seems to be the conflict and turning point in the novel. The reader is exposed to the childless state of the Oakleys, which now made Maurice and his wife Leslie to extend all their love to Francis Oakley, who was only a half-brother to Maurice. Maurice Oakley and his wife's dream for Francis to marry Claire Lessing and settle in America was not in agreement with Francis's ambition and this factor contributed immensely to the failure of Francis later in life.

"The Theft" story narrated in Chapter Three is a clear case of frame up and blackmail on a helpless Black American family of Berry Hamilton by Maurice Oakley's brother, Francis. Contrary to the truth of Francis's ostentatious and 
extravagant living, he gave a wrong impression of sadness over the loss of his money totaling nine hundred and eighty-six dollars. Francis claimed to have shamefully accepted most of them from his half-brother, Maurice. His pretences would hardly give one any clue that Francis, an artist by profession, actually stole this money. It was much later, in chapter 13, after the Hamilton's family had been ruined and disintegrated that Francis really confessed his use of the money to satisfy a "dark-eyed mademoiselle" who he loved and wanted to marry (Dunbar, 190 - 193)

The heartlessness of the white men over their slave workers is further exposed in Chapter Four entitled "The Justice of Men". Berry Hamilton was investigated and convicted by his master Maurice Oakley, against the norm of allowing the detective officer to do his duty. All the pleadings of Fannie, Berry's wife to the wife of her slave master, Mrs. Leslie Oakley fell on deaf ears, as the woman corroborated with her husband in his wickedness:

Fannie was utterly hopeless. She had laid down whatever pride had been hers and gone to plead with Maurice Oakley for her husband's freedom, and she had seen his hard, set face. She had gone upon her knees before his wife to cite Berry's long fidelity.

"Oh Mrs.' Oakley," she cried, "if he did steal de money, we've got enough saved to make it good. Let him go! Let him go! “

"Then you admit that he did steal"

Mrs. Oakley had taken her up sharply? “ "Oh, I didn't say dat; I did n't mean dat."

"That will do, Fannie. I understand perfectly.

You should have confessed that long ago."

"But I ain't confessin'! I ain't! He didn't - "

"You may go." (59) 
The dehumanization and denigration of blacks counted seriously in the novel. Among the wrong accusations made against Berry Hamilton as a result of the earlier discovery made of bank savings by him to the tune of eight hundred dollars and over five hundred more added to his account on the purported day of the stealing, the fact that Berry had no rent and no bill to pay was not considered. He was prejudged by his master to be a thief. The narrator of the novel stated that 'His clothes came from his master, and Kitty and Fannie looked to their mistress for the larger number of their supplies.' (Dunbar: 57) Fannie also realized fifteen dollars a month and Joe had been saving for two years. The attitude of the fellow blacks to Berry's family is most disgusting when Berry is wrongly indicted of theft from his slave master:

"Mistah Rich Niggah," said another. "He wanted to dress his wife an' chillen lak white folks, did he? By de time de jedge git thoo wid him he won't be hol' in his haid so high."

"W'y, dat gal o' his' n," broke in old Isaac Brown indignantly, " $w$ ' $y$, she would $n$; speak to my gal, Minty, when she met huh on de street. I reckon she come down off' $\mathrm{n}$ huh high hoss now." (51)

The inhuman treatment meted to the Hamilton's eventually reached the climax when the family was made the outcasts. The wife of Berry and his children were compelled by Maurice Oakley to quit their quarters after the Grand Jury sat and convicted Berry Hamilton of ten years imprisonment with hard labour. This scene is also the climax of the novel as the Hamilton's unity disintegrated and the family lost their innocence, while the moral foundation of the children was forcefully corrupted. After fruitless search for a new home and employment by both Fannie and Joe, and discovering that the 
family was more or less stigmatized, they had no choice than shifting down North to New York. Dunbar states that:

To the provincial coming to New York for the first time, ignorant and unknown, the city presents a notable mingling of the qualities of cheeriness and gloom. If he have [sic] any eye at all for the beautiful, he cannot help experiencing a thrill as he crosses the ferry over the river filled with plying craft and catches the first sight of the spires and buildings of New York. If he have [sic] the right stuff in him, a something will take possession of him that will grip him again every time he returns to the scene and will make him long and hunger for the place when he is away from it. Later, the lights in the busy streets will bewilder and entice him. He will feel shy and helpless amid the hurrying crowds. A new emotion will take his heart as the people hasten by him, - a feeling of loneliness, almost of grief, that with all of these souls about him he knows not one and not one of them cares for him. (82)

The Hamiltons' arrival in New York on a clear October day prepared them for the hilarious and free life of the urban city that ruins the excited and psychedelic mind. The four-storied brick dwelling on Twenty-Seventh Street where the family was eventually directed had its look of grandeur. Their proprietress, Mrs. Jones, was kindly disposed towards them as she allowed them to rent two rooms and use her kitchen until the family decided whether or not to take a flat. Unfortunately, the same Mr. Thomas that led the family to their new residence brought about their exposure and eventual doom in New York. At first the new place in New York seemed to be promising a better condition than their former. Notice the different ways that Joe and his sister Kit were affected in the New York environment: 
The boy was wild with enthusiasm and with a desire to be a part of all that the metropolis meant. In the evening he saw the young fellows passing by dressed in their spruce clothes, and he wondered with a sort of envy where they could be going. Back home (i.e. in the Southern plantations), there had been no place much worth going to, except church and one or two people's houses...

No such radical emotions, however, troubled Kit's mind. She too stood at the windows and looked down into the street. There was a sort of complacent calm in the manner in which she viewed the girls' hats and dresses.

While Joe sees his early environment as narrow and nursing a sense of anger over this awareness, Kitty 'had a certain selfrespect which made her value herself and her own traditions higher than her brother did his' (89).

Mr. William Thomas's corrupt nature gingered him to offer showing Joe something of the town of New York City. A loquacious little man with a confident air, born of an intense admiration of himself, he was the idol of a number of servantgirls, and he exploited this advantage to deflowering Kitty later. His promises of showing Kitty the stature of Liberty, Coonely Island and the best of New York shows was a good attraction to the Hamiltons. All the efforts of Mrs. Fannie Hamilton to keep her young ones away from the urban squalor proved abortive as the forces of easy life pulled them into the mainstream of alcoholic drinks, smoking, womanizing and night club activities, culminating in Joe's giving his life to a whore and later strangulating the same girl who introduced him to city life, succored him and also later threw him out of her life. 
Hattie's standing by Joe in time of need helped him to stand boldly without any fear or sense of guilt when Minty Brown visited from the South and attempted blacklisting the Hamiltons. Members of Joe's fraternity included characters like Sadness, Thomas, Mr. Tumer (the bar proprietor), Skaggsy (the reporter from New York 'Universe' newspaper) and Maudie his girlfriend. The fraternity gave Joe some sense of belonging and protection, although they later contributed to ruining his life. The reader is exposed to the picture of introduction of Joe to the fraternity as follows: "As they stood at the bar, the men began strolling up one by one. Each in his turn was introduced to Joe. They were very polite. They treated him with a pale, dignified, high-minded respect that menaced his pocket-book and possessions." (113).

The Banner Club is described as an institution for the lower education of Negro youth. People of all classes attend it from every part of the country. Joe got introduced to this club by Thomas, while his sister Kitty was later employed also as a singer in the club through the influence of Hattie Sterling. It was the nature of this club that easily connected Joe and Skaggsy who is a white man, and later investigator of Joe's claim of his father's innocence in the case of alleged theft of Francis Oakley's money. It is worthy of note that the whites referred to the Banner Club as "nigger club" (121) but for people like Skaggsy, the club offered good inspiration. Although Skaggsy claimed that his father had a big plantation and owned lots of slaves, the reader notices the lies exhibited by this boy as the novel informs that "the truth about the young reporter (Skaggsy) was that he was born and reared on a Vermont farm, where his early life was passed in fighting for his very subsistence" (122).

On the side of Mrs. Hamilton, she lately noticed the distancing of her children, as Joe had given his life, time and money to Hattie Sterling, while her daughter Kitty had equally 
grown secretive and sly. The lines of The Sport of the Gods give us a better picture:

Mrs. Hamilton could not understand it all and many a night she wept and prayed over the change in this child of her heart. There were times when she felt that there was nothing left to work or fight for. The letters from Berry in prison became fewer and fewer. He was sinking into the dull, dead routine of his life. Her own letters to him fell off. It was hard getting the children to write. They did not want to be bothered, and she could not write for herself. So in the weeks and months that followed she drifted farther away from her children and husband and all the traditions of her life. (131)

Despite the sufferings and burdens placed on the Hamilton's by the injustices and inhuman treatment of the Southern Americans, a girl named Minty Brown later traced them to New York to finish up whatever damages that remained to be dished out to the family. Fannie Hamilton's hostility to Minty Brown, following the family's earlier experience in the South further worsened the situation for them in the North city of New York, as Minty further created a ground for the family to be publicly stigmatized in New York. Only Joe's socialization with the fraternity in Banner Club saved him from the new scene created by Minty Brown about the alleged Hamilton family's involvement in crime.

Mrs. Jones (who is the new landlady of Hamiltons) ordered Mrs. Hamilton out of her house because Minty announced that Mrs. Hamilton ran out of town with her children because her husband Mr. Hamilton was in penitentiary. To further humiliate the family, Mrs. Jones informed Mrs. Hamilton of the people's awareness that her 
daughter Kitty was always with their neighbour Mr. Thomas who was not divorced from his wife

She flashed a vindictive glance at the girl, who turned deadly pale and dropped her head in her hand.

'You daih to say dat, Mrs.' Jones, you dat fust interduced my gal to dat man and got huh to go out wid him? I reckon you'd bettah go now," And Mrs. Jones looked at Fannie's face and obeyed. (139)

The conflict that later ensued from this between Joe and his mother pushed the boy to the street with more despair and frustration, leading to final state of annihilation. Kitty saw herself in a state of stupor and all things fell apart at this point: the mother having a new husband, the daughter becoming loose and wild due to serious pressure on her by social circumstances, while the son turned into an addicted drunk and eventually a strangler.

Through the encouragements of his friend Sadness, Joe came to know that Sadness' father was hung by the best citizens of Texas; Viola (a member of the club) killed another woman with an iron stool at the age of nineteen, and that Barney has been indicted twice for pocket picking, Poor Wallace came into the club with about two thousand dollars, the proceeds from the sale of a house left by his father, wasted it and depended on others. According to Sadness:

From now on Wallace will live, eat, drink, and sleep at the expense of others, and will forget to mourn his lost money. He will go on this way until, broken and useless, the poor - house or the potter's field gets him. Oh it's a fine, rich life, my lad. I know you'll like it. It has plenty of stir in it, and a man never gets lonesome. Only the rich are lonesome. It's only the 
independent who depends upon others. (Dunbar:

149)

These situations above were the unfortunate picture of the sordidness of black life in America.

It was much later in Chapter Thirteen of the novel The Sport of the Gods that mention is made of the Oakley family again. Maurice Oakley had grown more suspicious of his servants and the wife backed him up in all that he did. They frequently received letters from Frank until the latest letter which gave Maurice the greatest shock of his life. Frank was indeed the architect of his destiny. He confessed through the letter that, "the money from my cabinet was not stolen save by myself. I am a liar and a thief but your eyes shall never tell me so." (192). Maurice fainted after reading the letter, but the wife eventually disclosed the contents of the letter before her husband recovered and seized it, warning that "no one must ever know what is in this letter," (194). On the question of wrongs done to Berry Hamilton, Maurice wondered:

"What of Berry?" he cried, starting up excitedly.

"What is Berry to Frank? What is that nigger to

my brother? What are his sufferings to the honour of my family and name?" (196)

The last hope that Joe Hamilton had in Hattie hit the rocks when he was thrown out of the lady's life, for being a cur (i.e. a low worthless person). Drinking himself into a state of stupor, Joe threatened to kill Hattie. It was in that state of mind that he made an utterance which helped Skaggsy to go into thorough investigation on the father of Joe. Dunbar makes Joe to say

Say, d' ever tell y' 'bout the ol' man?

He never stole that money. Know he di' n'.'

He threatened to fall asleep now, but the reporter was all alert. He scented a story. 
"By Jove!' he exclaimed, "did you hear that? Bet the chap stole it himself and's letting the old man suffer for it. Great story, ain't it? Come, come, wake up here. Three more, Jack. What about your father? "

"Father? Who's father. Oh, do' bother me. What?"

"Here, here, tell us about your father and the money. If he didn't steal it, who did?"

"Who did? That' 's it, who did? Ol' man di' n' steal it, know he di' n'.'(205)

Joe's final strangulation of Hattie was because 'he was' according to him, 'put out' after Hattie made him what he was. The novel states that:

His fingers had closed over her throat just where the gown had left it temptingly bare.

They gave it the caress of death. She struggled. They held her. Her eyes prayed to his.

But his were the fire of hell. She fell back upon her pillow in silence. He had not uttered a word. He held her." (209)

Joe was found in a chair he sank after killing Hattie, and he sat there until the officers found him. The expression in pages 212 to 214 of the novel exemplifies what the typical whites think of the blacks in America. Part of this is that the blacks should be confined to the villages and country districts, of the South, where they cannot battle with the terrible force of a strange and unusual environment, they should be made to imbibe the culture of simplicity, they should be taught to value agriculture more than bad arts, it was better for them to sing to God across the Southern fields than to dance for rowdies in the Northern halls. 
Back at the Hamilton's home, Joe Hamilton's mother had shared enough grief that

she only remembered that he was her son, and wept for him as such. The woman had earlier entered into a new marriage contract with $\mathrm{Mr}$. Gibson, being convinced by the new spouse that she was no longer married to her poor husband, since a penitentiary sentence is the same as a divorce." (168)

Kitty on her own side felt the arrest and subsequent conviction of her brother. "She felt the shame of it keenly, and some of the grief" (Dunbar, 215). Their father Berry Hamilton was languishing in his Southern prison and knew nothing of the entire problem, since no letters had passed between him and his family for over two years.

It was Skaggsy's theory that saved Mr. Hamilton and eventually restored his re-union with his wife. Going down South with a train, Skaggsy lodged in a hotel to investigate and authenticate Joe's claim for publication in his newspaper, The Universe. The reporter lodged in the Continental Hotel and listened through the customers for information. This was not difficult as the bar of the hotel was still the gatheringplace of some of the city's choice spirits of the old regime. Skaggsy insinuated that he was looking around for business prospects and this assisted him in actualizing his goal. Five years after the Hamilton's family left the South, things have not changed much in the hotel. Through his new acquaintance with Beachfield. Davis and Horace Talbot, Skaggsy got clues that led him to Maurice Oakley from where he got the facts of Joe's insinuatuion. Colonel Saunders' interjection that he is one of those that believed in the innocence of Berry Hamilton seriously helped Skaggsy in hearing the detailed news about 
the developments in Oakley's family house recently, from four years back (Dunbar, 224 -227) At the Oakley's house, the scene was quite different and eccentric, as Skaggsy had to apply all his wisdom to see the old recluse, clutching at his breast pocket so often. It was Skaggsy's tricking the old man that he was coming from Paris that led Maurice out and the interest for his brother betrayed him in letting out the secret in his pocket to the reporter (Skaggsy). The reporter deserved a serious commendation as he was the voice of the voiceless. Through him, the news was published in The Universe and there is pressure from the governor for Berry Hamilton to obtain his liberty. According to Dunbar:

The Universe had always claimed to be the friend of all poor and oppressed humanity, and every once in a while it did something to substantiate its claim, whereupon it stood off and said to the public, "Look you what we have done, and behold how great we are, the friend of the people!" The Universe was yellow.

The consequences of the publication were total melancholic disorder in Maurice Oakley and big shame to all the Southerners, while Berry Hamilton gained his civil liberty. This development is a big blow to the Americans in particular and to the white race in general, it exposes to a great extent the problem of racism, oppression and slavery against the black race. The old man's (Berry) discovery of the total wreck that had overtaken his household after leaving the cell is better imagined. This is a clear case of oppression. The white man Skaggsy, who is the Universe reporter was in the vanguard of leading him back to his 'family' now at New York, and then to his wife's new home with Mr. Gibson, where he was initially rejected by his estranged wife Fannie, but later 'reaccepted by the work of fate'. The novel ended in a sober 
way, with Gibson killed in a fight at the race-track and Fannie going back to her husband Berry.

New York held nothing for the family save sad memories and the couple had to go back southward, back to Oakley's house, which is the only place they could call home. Leslie Oakley was aware of their coming and personally reopened and refurbished the little cottage in the yard for them. As an amendment, the old woman begged the couple to spend the rest of their days and be in peace and comfort there. The couple sat together with clasped hands listening to the shrieks of the mad Oakley many a night across the yard and ruminated over what he had brought to them and to himself.

What a sad and helpless life for the Hamiltons. One wonders whether the blacks in America and elsewhere are generally doomed to go this way.

\section{Conclusion}

Books authored by Black writers brought the Black American literature to limelight especially from the 1970s, as more markets were created for them and the authors equally started winning different awards. Academics equally acknowledged this species of literature within this period as an accepted genre of American literature. Authors like James Emmanuel, Toni Morrison (who aided the promotion of Black literature when she worked as an editor for Random House in 1960s and 70s), Alice Walker who wrote The Color purple, an epistolary novel (a book written in form of letters), which tells the story of Celie, a young woman who is sexually abused by her stepfather and then forced to marry a man who physically abuses her, Alex Haley, Gayl Jones, Rasheed Clark, Ishmael Reed, Jamaica Kincaid, Randall Kenan, and John Edgar Widernan, among others have brought this genre of literature to international recognition. 
Critics of Black American literature hold the view that while Black American literature is well accepted in the United States, there are too many views on its significance, traditions, and theories. The supporters of this genre are of the view that this literature emerged from the experience of Blacks in the United States, especially with regard to historic racism and discrimination, and is an attempt to refute the dominant cultures, literature and power (that is America and other Europeans). A faction that supports the African American literature sees it as part of balkanization of American literature. There are also those in the African American community that detest the way in which their literature sometimes portrayed the blacks. Some criticisms levelled against the Black American literature over the years emanated from the African American community, part of which is that black literature does not sometimes portray black people in a positive light.

The consensus is that American literature is not breaking apart because of the new genres like Black American literature, but is instead reflecting the increasing diversity of the United States and showing more signs of diversity than ever before in its history. The fact still remains that the Black American literature is really a microcosm of the diasporic idea of the whole black people the world over on negritude. Black is therefore beautiful, cultural imperialism notwithstanding.

Dunbar's reflection over the segregation and marginalization experienced by the blacks in The Sport of the Gods assumed a very pitiable state. An analysis of his view shows that Hamilton suffered unjustly in the hands of his master because he is a helpless black man. His human rights were seriously abused by both his master Maurice and the Police because blacks in the novel were segregated against. It is equally pitiable that the black people in the novel hated themselves and so did not have a one united voice. They rather suffered from inferiority complex and colonial mentality enforced on them by the whites. Hamilton's earlier successful 
family life was a big source of worry and discomfort not only for the whites but for his fellow blacks, and they really celebrated his fall when his master Maurice got him unjustly accused, arrested and sent to jail. This state of the black people in America was indeed quite pitiable, although there seemed to be a light at the end of the tunnel by the action exhibited by the young American journalist, Skaggsy who had fraternized with the blacks.

Ogene Mbanefo S. is of the Department of English Language and Literature, Nnamdi Azikiwe University, Awka

\section{Works Cited}

Adams, Catherine; Pleck, Elizabeth. Love of Freedom. New York: Oxford University Press. 2010.

African American Literature - Wikipedia, the Free Encyclopedia Web. Modified on 20 May 2013

Gates, Henry Louis. The Norton Anthology of African American Literature. New York: W.W. Norton. 1997.

http://www.wikipediafoundation.org/ last modified on 2 September 2008, at 05:30.

"Harlem Renaissance." Encyclopaedia Britannica. Ultimate Reference Suite. Chicago: Encyclopaedia

Britannica, 2012.

Harris, Leslie M. "African Americans." Microsoft ${ }^{\circledR}$ Encarta ® 2006 [CD]. Redmond, WA: Microsoft Corporation, 2005.

"Paul Laurence Dunbar." Microsoft ® Encarta ® 2006 [CD]. Redmond, WA: Microsoft Corporation, 2005 Paul Laurence Dunbar. The Sport of the Gods. Miami, Florida: Mnemosyne Publishing Inc., 1969. 